\title{
VIBRATION AS AN OCCUPATIONAL HAZARD IN THE WORK ENVIRONMENT OF LATVIA
}

\author{
Jānis Dundurs* and Žanna Martinsone ${ }^{\star *}$ \\ * Department of Occupational and Environmental Medicine, Rīga Stradiṇš University, Dzirciema iela 16, Rĩga, LV-1007, LATVIA \\ E-mail: janis.dundurs@ @ru.Iv \\ ** Institute of Occupational Safety and Environmental Health, Rīga Stradiṇš University, Dzirciema iela 16, Rīga, LV-1007, LATVIA
}

Communicated by Andrejs Skaǵers

\begin{abstract}
The aim of our study was to investigate vibration as an occupational health risk, conduct a survey and self-evaluation of health of the employees, carry out vibration measurements in different workplaces and to recommend practises for optimisation of work conditions. The results of analysis of employee's questionnaires and of measurements show that the vibration risk factor is a very topical issue and has been underestimated, particularly in branches like manufacture of timber wood products construction, metal processing etc. The number of vibration-caused occupational diseases in recent years has grown both in absolute figures and as percentage of the total number of occupational diseases indicating that the ratio of vibration-caused occupational diseases in Latvia is growing.
\end{abstract}

Key words: whole body vibration, hand arm vibration, vibration exposure, vibration-caused occupational diseases.

\section{INTRODUCTION}

Vibration is defined as oscillations of material particles (hard matter, liquids, gases) and their movement. Vibration that is transmitted through the worker's hands with work appliances, the operation of which is connected with strokes and rotation and causes risk to the worker's safety and health, is called hand and arm vibration (HAV). Vibration that is transmitted through the support surfaces of a standing or sitting employee and generally affects the whole body causing risk to the worker's safety and health, as whole-body vibration (WBV) (Seidel, 2008). The vibration in the work environment can be estimated as vibroacceleration $\left(\mathrm{m} / \mathrm{s}^{2}\right)$, which identifies the energy of oscillation and influence of vibration on the human body (Anonymous, 1997; Dundurs, 2008).

Both HAV and WBV are widespread in work processes connected with the manufacturing and processing of various materials (timber, metal, etc.), as well as with operation and maintenance of different machines (lorries, tractors, etc.) and equipment (production lines, motors, generators). Both types of vibrations create one of the most important risk factors in branches like timber processing and wood felling, metal processing, manufacturing, maintenance and repair of transport, construction, power production, food production, etc. (Taylor, 1994; Eglīte, 2000; Anonymous, 2006, Martinsone et al., 2007).

The aim of our study was to investigate vibration as an occupational health risk: to conduct a survey and self-evalu- ation of health of employees, to carry out vibration measurements in different workplaces, and to provide recommendations on optimisation of work conditions in Latvia.

\section{MATERIALS AND METHODS}

An employee survey was conducted using specially prepared questionnaires: Computer Assisted Telephone Interviews (CATI), ad hoc, Computer Assisted Personal Interviews $(\mathrm{CAPI})$, and self-addressed. Employers $(\mathrm{n}=1058)$ were asked to assess the number of employees in their companies who were exposed to vibration created by hand instruments, machines, etc. (i.e. hand and arm vibration) and vibration created by transport (i.e. whole-body vibration). Employees $(n=2455)$ were asked questions similar to those given to employers. The respondents were asked to supply answers using the following categories: all the time, nearly all the time, about $3 / 4(75 \%)$ of the time, about a half of the time, about 1/4 (25\%) of the time, nearly never, and never.

For the evaluation, Human-vibration Unit 2522 and Module BZ7116 plus Modular precision Sound level meter 2231) and International and Latvian standard methods (LVS EN ISO 2631-1:2003; LVS EN ISO 5349-1:2002; LVS EN ISO 5349-2:2002) were used. We carried out 114 HAV measurements during the period from 2002 to 2006, and 344 WBV measurements in the period from 1998 to 2005, in workplaces/processes.

The data of measurements were analysed using descriptive statistics and statistical method $-\chi^{2}$ (Chi square test) to find 
statistical significance $(P<0.05)$ between parameters. All data were analysed by SPSS 16.0 and MS Office Vista Excel softwares.

\section{RESULTS}

Generally, $19.7 \%$ of employers stated that in their companies employees were exposed to vibration created by hand instruments, machines, etc, and $16.3 \%$ reported exposure to vibration created by transport. Hand and arm vibration was most common in branches like manufacture of timber, wood and cork products, furniture (64.6\%), construction $(63.5 \%)$, output industry $(43.4 \%)$, processing industry $(32.9 \%)$, agriculture, forestry, hunting $(32.0 \%)$, power, gas and water supply $(30.8 \%)$, and health and social care (28.5). Exposure to the vibration of hand instruments, machines, etc. was observed more in large enterprises compared to small $(16.2 \%$ in companies with 1-9 employees, $26.4 \%$ in companies with 10-49 employees, $38.1 \%$ in companies with 50-249 employees, and $47.7 \%$ in companies with 250 and more employees). Occurrence of HAV was higher in companies formed before $1990(29.3 \%)$ than in new companies (19911995 - 20.8\%; 1996-2000 - 18.2\%; 2001-2005 $19.3 \%)$. Differences in exposure to vibration also depended on ownership of companies: mainly local ownership $(20.3 \%)$ of companies, equal local and foreign ownership $(21.9 \%)$ and mostly foreign ownership (9.3\%). Rear hand and arm vibration was mentioned as a risk factor by respondents from Rìga (15.5\%), from other towns (21.8\%), and most often by respondents from villages and countryside $(31.7 \%)$.

Those exposed to the whole-body vibration more often are workers employed in the output industry $(84.1 \%)$, manufacture of timber, wood and cork products, furniture (64.6\%), agriculture, forestry, hunting companies (61.5\%), fishing companies (53.6\%), construction (34.0\%). Similar to HAV, those exposed to vibration created by transport more often are employees in large companies compared to small (12.2\% in companies with the number of the employed 1-9, $23.5 \%$ in companies with 10-49 employed, $42.3 \%$ in companies with 50-249 workers, and $45.0 \%$ in companies with 250 and more workers). Regarding frequency of WBV exposure by the year of company founding, employees had a greater chance to be exposed in companies formed before $1990(33.7 \%)$, compared to younger companies (19911995 - 23.5\%; 1996-2000 - 11.8\%; 2001-2005$13.7 \%)$. Whole-body vibration was reported less in the private sector $(15.9 \%)$ than in public sector $(29.0 \%)$. No significant difference was observed depending on the ownership (mainly local ownership - $16.7 \%$, mainly foreign $14.1 \%$, equal local and foreign $-6.7 \%$ ). Vibration created by transport was more common in companies located in villages and countryside $(29.0 \%)$, less often in other towns $(16.8 \%)$, and the least often - in Riga, the capital of Latvia $(12.9 \%)$.

In general according to the view of 2455 employees, $23.9 \%$ were, to a certain extent, exposed to HAV: most of them in construction (66.1\%) followed by production of metal, metal products, equipment mechanisms $(58.7 \%)$, manufacture of timber, wood and cork products, furniture (53.2\%). Men are more often exposed to HAV (43.7\%) than women $(8.0 \%)$. Vibration created by hand instruments, machines, etc. is recognized as a working environment risk factor similarly by age groups $(23.1 \%-28.1 \%$, except in the 55-74 year-old group who mentioned HAV in $19.0 \%$ cases). Similarly, there were no significant differences between nationalities (Latvians 23.0\%, Russians 26.1\%, others $23.6 \%$ ). Higher respondent education was associated with a lower HAV risk factor (elementary education $39.8 \%$, primary education or unfinished secondary education $36.3 \%$, secondary education $29.1 \%$, secondary specialised education $26.9 \%$, higher education $10.3 \%$ ). Respondents from the private sector (29.5\%) more often mentioned HAV than respondents from the state $(13.7 \%)$ and public $(20.5 \%)$ sectors.

The number of respondents who mentioned HAV did not depend on the size of company where they were working (1-9 workers - 22.3\%, 10-49 workers - 23.9\%, 50-249 workers - 25.2\%, 250 and more workers - 24.6\%). A higher worker basic wage (in Latvian lats, LVL) was associated with greater exposure to HAV: up to $90 \mathrm{LVL}-$ 18.1\%, 91-150 LVL - 22.2\%, 151-250 LVL - 26.1\%, $251 \mathrm{LVL}$ and more - 27.7\%). Slightly more often HAV was mentioned by respondents who received their wage in "envelopes" (sometimes - 31.5\%, every month - 42.7\%, never - 20.3\%). According to the employee view, HAV was reported more often by those employed in a small village, village, and in the countryside $(31.7 \%)$. Considering the type of settlement where the main workplace was located, no significant differences were noticed $(20.9 \%$ $24.1 \%)$.

A total of $16.9 \%$ of respondents considered that they were exposed to whole-body vibration: most often by those working in fishing (46.4\%), agriculture, forestry, hunting $(38.8 \%)$, and construction $(32.1 \%)$. Men were more often exposed to the WBV $(31.6 \%)$ than women $(5.0 \%)$. Vibration created by transport was recognised as a work environment risk factor similarly by all age groups $(15.7 \%$ $19.7 \%$, except in 55-74 years old respondents who have mentioned WBV in $12.3 \%$ cases). Similarly, there were no significant differences between nationalities (Latvians $16.8 \%$, Russians $18.1 \%$, others $14.3 \%$ ). A higher level of respondent education was associated with a lower amount of reported HAV risk (elementary education $-31.3 \%$, primary education or unfinished secondary education $21.9 \%$, secondary education $-17.5 \%$, secondary specialised education $-19.3 \%$, higher education $-10.9 \%)$. No significant differences were observed among respondents representing state sector $(14.9 \%)$, private sector $(18.1 \%)$ or public sector $(10.3 \%)$.

The number of respondents who mentioned WBV as a risk did not depend on the size of company where they are working (1-9 workers - 14.6\%, 10-49 workers - 17.6\%, 50-249 workers - 16.0\%, 250 and more workers - 
19.6\%). A higher worker basic wage was associated with greater whole body-vibration risk: up to LVL $90-11.1 \%$, LVL 91-150 - 13.6\%, LVL 151-250 - 18.5\%, LVL 251 and more - 20.9\%). This might indicate that workers working with appliances need higher qualification, thus their wage is higher, as a similar relationship was observed also in relation to the number of respondents who answered that they work with work appliances: up to LVL 90 $16.0 \%$, LVL $91-150$ - 20.7\%, LVL 151-250 - 24.9\%, LVL 251 and more - 26.5\%). Whole-body vibration was mentioned slightly more often by respondents who receive their wage in "envelopes" (sometimes $21.4 \%$, every month $23.4 \%$, never $15.3 \%$ ). A greater number of employees employed in a small village, village, and countryside (23.2\%) considered that they were exposed to HAV. Considering the type of settlement where the main workplace was located, no significant differences were noticed among the groups of respondents $(12.6 \%-17.8 \%)$.

During inquiry the employed were asked a question whether they had any health disorders, which, in their view, were caused by harmful factors of the work environment. Respondents exposed to vibration created by hand instruments and machines mentioned health disorders more often than the average in Latvia. Women mentioned health disorders much more often than men (women $47.3 \%$, men 26.8\%). Young respondents mentioned health disorders less than older groups (18-24 years old - 20.6\%, 25-34 years old $-29.9 \%$, 35-44 years old $-36.1 \%$, 45-54 years old $-25.4 \%, 55-74$ years old $-39.7 \%)$. Yet, the cause of health disorders of the respondents cannot be considered to always be due to vibration. For example, health disorders of a worker working in timber processing or metal processing are caused by physical overwork from handling loads and work in a noisy environment. It is not possible to differentiate health problems caused by different factors.

Respondents, who in their workplace are exposed to vibration caused by transport, mentioned health disorders slightly more often $(25.8 \%)$ than the average in Latvia $(21.3 \%)$. Women in this group had health disorders slightly more often than men $(28.9 \%$ and $25.2 \%$, respectively). Young respondents mentioned health disorders less than older groups (18-24 years old $-20.4 \%, 25-34$ years old $-25.0 \%$, 35-44 years old $-27.7 \%$, 45-54 years old $-20.5 \%$, $55-74$ years old $-39.1 \%)$. Yet we cannot discern the cause of the reported health disorders.

Occupational health and safety $(\mathrm{OSH})$ specialists $(\mathrm{n}=86)$ who have acquired or are acquiring higher professional education were asked to mention ten most significant/essential working environment risk factors in the companies they are working in (including companies providing the services of a certified specialist or notified body). Hand and arm vibration was mentioned as the $12^{\text {th }}$ most important risk factor (HAV was mentioned by $36.0 \%$ respondents), and WBV was mentioned as the $16^{\text {th }}$ most essential factor (mentioned by $18.6 \%$ respondents).
The following question was asked: "Evaluate, please, to what extent are the CM (Cabinet of Ministers) Regulation No. 284 "Labour protection requirements regarding risk in working environment created by vibration" observed in Latvian companies (institutions). When answering use a 10 point scale, where 10 means 'observed fully', and 1 - 'not observed at all"'. According to the view of OSH specialists, observation of the above regulation was evaluated by 5.0 points. This score was a comparatively low index among regulatory enactments, the observation of which they were asked to evaluate (indexes are within the range from 4.8 for CM Regulation No. 427 "Election of trusted persons and operation procedure" up to 7.0 points - CM Regulation No. 585 "Procedure for investigation and recording of accidents at work").

Hand and arm vibration measurement results showed that in 24 work places/processes action was needed to reduce HAV and in 22 cases the values exceeded the HAV boundary value (Table 1). In 2002 and 2004, all vibration measurements exceeded the exposure boundary value, yet the number of measurements made was small $(\mathrm{n}=3$ in 2002 and $\mathrm{n}=$ 1 in 2003). In 2005 and 2006, in 29\% (21\% + 8\%) and $46 \%$ $(22 \%+24 \%)$ work places/processes employees were exposed to increased vibration impact $\left(\geq 2.5 \mathrm{~m} / \mathrm{s}^{2}\right)$.

T a ble 1

MEASUREMENT OF HAND AND ARM VIBRATION EXPOSURES $\mathrm{A}(8)$

\begin{tabular}{l|c|c|c|c|c|c}
\hline \multirow{2}{*}{$\begin{array}{l}\text { Vibration expo- } \\
\text { sure } \mathrm{A}(8), \mathrm{m} / \mathrm{s}^{2}\end{array}$} & \multicolumn{5}{|c|}{ Number of measurements per year } & \multirow{2}{*}{ Total } \\
\cline { 2 - 7 } & 2002 & 2003 & 2004 & 2005 & 2006 & \\
\hline 2 & - & 6 & - & - & - & 6 \\
$\geq 2$ & 3 & 1 & 1 & - & - & 5 \\
Total & 3 & 7 & 1 & - & - & 11 \\
$<2.5$ & - & - & - & 27 & 35 & 62 \\
$2.5 \leq \mathrm{A}(8)<5$ & - & - & - & 8 & 16 & 24 \\
$\geq 5$ & - & - & - & 3 & 14 & 17 \\
Total & - & - & - & 38 & 65 & 103 \\
Total & & & & & & 114 \\
\end{tabular}

$\mathrm{A}(8), 8 \mathrm{~h}$ daily vibration exposure

In 2005 and 2006, the highest average HAV level was in construction $-13.9 \pm 2.8 \mathrm{~m} / \mathrm{s}^{2}$ and $32.8 \pm 20.6 \mathrm{~m} / \mathrm{s}^{2}$. In 2006, the highest HAV level was observed in finished metal product (except machines and equipment) industries - 12.7 $\pm 1.4 \mathrm{~m} / \mathrm{s}^{2}(P<0.05)$. The highest HAV level was observed in construction, caused by the use of different hand instruments. It is important to know the duration and magnitude of HAV exposure to evaluate the health risk to employees (Burström et al., 2009).

In 25 cases $(7.0 \%)$ attention should be paid to the reduction of WBV, and in 123 cases $(36.0 \%) \mathrm{WBV}$ exceeded the boundary values (up to $2005-0.5 \mathrm{~m} / \mathrm{s}^{2}$, from $2005-$ $1.15 \mathrm{~m} / \mathrm{s}^{2} ; P<0.05$ ) (Table 2).

Increased exposure of WBV reaching $100 \%$ was observed in 2001, when in two evaluated workplaces it exceeded the 
Table 2

MEASUREMENT OF WHOLE BODY VIBRATION EXPOSURES A(8)

\begin{tabular}{|c|c|c|c|c|c|c|c|c|c|}
\hline \multirow{2}{*}{$\begin{array}{c}\text { Vibration ex- } \\
\text { posure } A(8), \\
\mathrm{m} / \mathrm{s}^{2} \\
\end{array}$} & \multicolumn{8}{|c|}{ Number of measurements per year } & \multirow[t]{2}{*}{ Total } \\
\hline & 1998 & 1999 & 2000 & 2001 & 2002 & 2003 & 2004 & 2005 & \\
\hline$<0.5$ & 2 & 13 & 5 & - & 41 & 55 & 45 & 35 & 196 \\
\hline$\geq 0.5$ & 3 & 3 & - & 2 & 33 & 31 & 21 & - & 93 \\
\hline $\begin{array}{l}0.5 \leq \mathrm{A}(8)< \\
1.15\end{array}$ & - & - & - & - & - & - & - & 25 & 25 \\
\hline$\geq 1.15$ & - & - & - & - & - & - & - & 30 & 30 \\
\hline Total & 5 & 16 & 5 & 2 & 74 & 86 & 66 & 90 & 344 \\
\hline
\end{tabular}

$\mathrm{A}(8), 8 \mathrm{~h}$ daily vibration exposure

exposure boundary value of $0.5 \mathrm{~m} / \mathrm{s}^{2}$. Also, in 2002 , WBV exposure exceeded the boundary value in $45 \%$ cases $(n=$ $33)$, in 2004 in $32 \%(n=21)$ and in 2005 in $61 \%$ cases. Whole-body vibration needs to be reduced in these work places/processes (action value $-0.5 \mathrm{~m} / \mathrm{s}^{2}$ ), of which in $33 \%$ cases the vibration also exceeded the exposure boundary value $\left(1.15 \mathrm{~m} / \mathrm{s}^{2}\right)$. The highest WBV average level was in construction $-7.09 \mathrm{~m} / \mathrm{s}^{2}$ (in 2002), $3.05 \mathrm{~m} / \mathrm{s}^{2}$ (in 2003), $1.16 \mathrm{~m} / \mathrm{s}^{2}$ (in 2004), and $2.18 \mathrm{~m} / \mathrm{s}^{2}$ (in 2005). In 2005, high WBV level was observed in electric machine and device production $\left(6.03 \mathrm{~m} / \mathrm{s}^{2}\right)$. The results show that in construction there was observed not only the highest HAV risk but also a considerably increased WBV risk, caused by different means of transport and operation of equipment.

\section{DISCUSSION}

During the "Living conditions in Latvia" (Ostlands et al., 1996), about $13.0 \%$ of the employed mentioned that they were exposed to the influence (not specifying what) of strong vibration at the workplace. Similarly, during the study "Living conditions in Latvia" carried out in 1999, $13.5 \%$ of respondents pointed out that at their workplace they were regularly exposed to vibration (not specifying what) (men $21.3 \%$, women $5.2 \%, 11.3 \%$ in public sector, $16.2 \%$ in private sector).

According to the study "Working conditions in the countries in pre-accession period and candidate countries" (Anonymous, 2003), in Latvia about $10.4 \%$ active inhabitants (self-employed and employed persons over 15 years) reported that they were exposed to vibration all the time (on average $6.3 \%$ in new member states), $6.8 \%$ nearly all the time (5.4\% in new member states), $4.2 \%$ about half the time (3.7\% in new member states), $6.5 \%$ about $1 / 4$ of the working time (6.8\% in new member states), $10.0 \%$ nearly never (11.1\% in new member states). During the survey of the health of Latvian population (Anonymous, 2004), 25.7\% men and $8.7 \%$ women mentioned vibration as an existing work environment risk factor at their work places. Most often vibration was mentioned by respondents having elementary and less education $(22.3 \%)$ and secondary education
(19.1\%), most seldom by those with higher education $(9.1 \%)$.

In a public opinion poll on the operation of the State Labour Inspectorate (Anonymous, 2005), the employers were asked how many workers employed at their companies were exposed to the influence of vibration, not specifying HAV or WBV. Accordingly, 2.9\% employers considered that all employed in their companies were exposed to vibration, $3.1 \%$ - the majority, $4.3 \%$ - about a half, $11.6 \%$ - less than a half, $69.0 \%$ - never, and $9.0 \%$ failed to answer the question. The same question was put to the general population: $5.3 \%$ respondents pointed out that they were exposed to the influence of vibration all the time, $5.0 \%$ - most working time, $2.9 \%$ - about half the time, $7.7 \%$ - less than half the time, $63.5 \%$ - never, and $15.6 \%$ respondents failed to answer the question. In addition, the persons were asked whether any harmful condition had made a negative impact on their health. $3.3 \%$ of the population mentioned that vibration (not specifying which) had affected their health.

The studies show that employers, particularly in small companies and in Rìga, do not have vibration as a work environment risk factor. Risk sectors were fishery, agriculture, forestry, hunting, construction, manufacture of metal, metal product, equipment mechanisms and manufacture of timber, wood and cork products, and furniture. Vibration more often was mentioned as a risk factor in large companies, which might be explained by the lack of information of small company employers about work environment risk factors, as well as the unawareness of the problem. Worker risk groups were workers in small villages and in the country, as well as those with a lower level of education.

Until 1 July 2005, in Latvia, the vibration measurement procedure and exposure boundary values were determined by ISO 2631-1 "Mechanical vibration and shock - Evaluation of human exposure to whole-body vibration" the Appendix ISO 2631-1.2, in which the WBV exposure boundary value was $0.5 \mathrm{~m} / \mathrm{s}^{2}$ and HAV exposition was $2 \mathrm{~m} / \mathrm{s}^{2}$. Exposure boundary values mentioned in the Standard were used as recommended values for the evaluation of the influence of WBV and HAV.

The Regulation of the Cabinet of Ministers No. 284, "Labour protection requirements regarding risk in work environment created by vibration", became effective on 1 July 2005 (passed on 13.04.2005). This Regulation mentions International Standards LVS EN ISO 5349-1:2002, "Mechanical vibration - Measuring and evaluation of vibration transmitted by human hands, Part 1: General requirements"; LVS EN ISO 5349-2002, "Mechanical vibration - Measuring and evaluation of vibration transmitted by human hands, Part 2: Practical instructions for measurements in the workplace"; LVS ISO 2631-1:2003, "Mechanical vibration - Evaluation of human exposure to whole-body vibration, Part 1: "General requirements"; and LVS ISO 2631-2:2003, "Evaluation of human exposure to whole-body vibration, Part 2: Lasting and shock caused vibration in buildings (1 to 
$80 \mathrm{~Hz})$ ". The above CM Regulation states that the employed must not be exposed to HAV exceeding the vibration exposure daily boundary value of $5 \mathrm{~m} / \mathrm{s}^{2}$ for a standardised eight-hour period, and to WBV exceeding the vibration exposition daily boundary value of $1.15 \mathrm{~m} / \mathrm{s}^{2}$ for a standardised eight-hour period. This means that vibration exposure should not exceed those values.

The above regulation states the lowest vibration exposure $-2.5 \mathrm{~m} / \mathrm{s}^{2}$ for daily exposure of HAV and $0.5 \mathrm{~m} / \mathrm{s}^{2}$ for daily exposure of WBV. It further states that higher values can cause health disorders or hinder the employees in fulfilling their work. Therefore, in the case where only the daily exposure value is exceeded the employer must carry out appropriate activities to protect the employed against the harmful effect of vibration on their safety and health.

According to the requirements of the CM Regulation No. 527, "Procedure how to carry out compulsory medical examination" (passed on 08.06.2004), the frequency of health examinations for the employed who are exposed to the influence of vibration in working environment is once a year for HAV and once in two years for WBV.

The labour protection law states that risk factor evaluation must be carried out in the work places of all companies. Normally, this it is done by the OSH specialist or a notified body, not less than once a year. Risk factors present in the work place are recorded, among which there can be also HAV and WBV. To solve successfully vibration-related problems at work, the most significant vibration sources, type of vibration and duration of exposure must be determined. Where vibration in the workplace can create increased risk to the worker's health, the vibration levels are measured to evaluate objectively the vibration-caused risk in the specific work place. Vibration level measurements in the work place can be carried out by competent specialists as well as notified bodies and accredited laboratories using measurement equipment that is registered and calibrated according to the legislation. The Latvian Accreditation Office homepage identifies six laboratories that are accredited to carry out vibration measurements (LATAK, updated: 28.06.2006); however, during the study it was not possible to obtain data on how many measurements each laboratory has made.

The HAV measurement results show that the necessary vibration reduction activities at nearly one half of work places/processes are carried out. Most WBV measurements were carried starting from 2002 when regulatory enactments on the working environment risk evaluation became effective. Most HAV measurements were made in 2005 and 2006, which can be explained by measurements made within the framework of this project. Yet, it should be noted that the number of vibration measurements made is too small to represent the general condition in the country. However, WBC exceeding the exposure boundary values were observed at almost half of assessed work places/processes, and at these places vibration reduction activities should be carried out. Therefore, vibration risk factor is a very important issue that has been insufficiently analysed, particularly in branches like construction, metal processing, and others.

The most frequent problem of the employed working with vibrating hand instruments is HAV-caused "white-finger" syndrome. The influence of vibration can cause irreversible changes in the finger blood vessels and nerves, as well as in hand and arm tendons, muscles, bones and joints. The vibration-affected fingers turn white, they may loose strength of grip and the sensibility may lessen (unable to button up, etc.). The "white finger" syndrome is intensified by cold (Burström et al., 2009; Sauni et al., 2010; Van Rijn et al., 2010). Whole-body vibration most often causes fatigue, insomnia, headache, giddiness, nervousness (i.e. disorders of central nervous system), changes in the body movements (instability), pain in the back, calf muscles and feet numbness. The most often observed changes for drivers are negative changes of spine and also a negative effect on blood circulation, digestion, respiration, and muscle systems (Eglite, 2000; Palmer et al., 2003; Seidel, 2005 and 2008).

In Latvia, vibration-caused occupational diseases (both by local and general vibration) are classified as a vibration effect, not separating HAV- and WBV-caused health disorders (Anonymous, 2006). Also, when analysing occupational diseases caused by a specific type of vibration it is not rare that one patient has both hand and arm and whole body vibration-caused pathologies and it is impossible to separate the vibration effects. The frequency of vibrationcaused occupational diseases per 100000 employed in the last years has grown from 3.7 cases in 2000 to 16.0 cases in 2005 (Anonymous, 2007). The increase of the number of vibration-caused occupational diseases is similar to the number of noise-caused occupational weak hearing (Eglite, 2000).

The proportion of vibration-caused occupational disease from the total number of newly registered occupational diseases has grown from $4.5 \%$ in 2000 to $10.2 \%$ in 2005 . It should be noted that the percentage of vibration caused occupational diseases in 1993-1999 was relatively high (15.0\% in 1993 and $8.8 \%$ in 1999). However, like in the case of noise-caused hearing reduction, the total number of occupational diseases was very small. For example, the proportion of vibration-impact-caused diseases was $7.7 \%$ in 1996, among occupation diseases its frequency per 100000 employed was only 1.9 cases per 100000 workers. Similarly, in 2003, it was $9.2 \%$ proportion and 14.4 cases per 100000 workers.

The analysis of the incidence of vibration-caused occupational disease by sectors (calculated per 100000 workers in the respective sector) show that the fastest growth was in the transport, communication and telecommunication sectors (from 3.8 cases in 1998 to 58.3 cases in 2004), agriculture and forestry (from 3.8 cases in 1996 to 88.7 cases in 2005), and construction (from 2.0 cases in 1996 to 33.6 cases in 2004). In other branches, the frequency of diseases 
per 100000 employed has remained relatively stable (Anonymous, 2007; Martinsone et al., 2007).

The conclusions are:

1. Employers do not realise vibration as an occupational hazard. The number of vibration measurements made is too small to state that the measurement analyses represent the average situation in Latvia.

2. The number of vibration-caused occupational diseases in the last years has grown both in absolute figures and in percentage of the total number of occupational diseases, and this provides evidence that the ratio of vibration caused occupational diseases in Latvia is growing. It proves that in these sectors the attention of the employers should be turned to the necessity to carry out labour protection activities aimed at the prevention of possible after-effects.

\section{REFERENCES}

Anonymous (1997). International Standard 2631-1. Mechanical vibration and shock. Evaluation of human exposure to whole-body vibration. ISO. P. 31.

Anonymous (2007). Eiropas Struktūrfondu projekts (ESF). Darba apstākḷi un riski Latvijā [Work Conditions and Risks in Latvia]. Rīga: A/S Inspecta \& RSU DDVI. 146 lpp. (in Latvian).

Anonymous (2006). Valsts Darba inspekcijas (VDI) vadlīnijas. Darba aizsardzības prasības nodarbināto aizsardzībai pret vibrācijas radīto risku darba vidē [Occupational Safety Requirements of the Employees' Protection to Vibration Risk in the Work Environment]. Rīga: LR Valsts Darba inspekcija. 40 lpp. (in Latvian).

Anonymous (2005). Valsts Darba inspekcija. Sabiedriskās domas pētījums par Valsts Darba inspekcijas darbību [Public opinion research on the operation of the State Labour Inspectorate]. Rìga.

http://www.vdi.lv/aktual/atskaite_SKDS.pdf (in Latvian).

Anonymous (2004). 2003. gada Latvijas iedzīvotāju veselības apsekojuma rezultāti. Statistisko datu krājums [Results of Population Health Investigation in 2003 in Latvia]. Rīga: Centrālā Statistikas pārvalde. 187 lpp. (in Latvian).

Received 10 April 2010
Anonymous (2003). Eiropas Dzīves un darba apstākḷ uzlabošanas fonds. Darba apstākḷi valstīs pirmspievienošanās posmā un kandidātvalstīs [Work conditions in the countries in pre-accession period and candidate countries]. http://www.eurofond.eu.int/publications/files/EF0306LV.pdf (in Latvian).

Burström, L., Lundström, K., Hagberg, M., Nilsson, T. (2009). Vibrotactile perception and effects of short-term exposure to hand - arm vibration. Amer. Occup. Hyg., 53(5), 539-547.

Dundurs, J. (2008). Vides fizikālais piesārņojums [Physical pollution of environment]. Grām.: Vides veselība (385.-436. lpp.). Rīga: Rīgas Stradiṇa universitāte (in Latvian).

Eglīte, M. (2000). Vibrācijas iedarbība uz cilvēka organismu [Vibration influence on men]. Grām.: Darba medicīna (353.-370. 1pp.). Rīga (in Latvian).

Martinsone, Ž, Vanadziņš, I., Sprūdža, D., Eglīte, M., Baķe, M.Ā., Sudmalis, P., Piḳe, A., Mārtiṇsone I., Reste, J., Dumbrovska, S. (2007) Kokapstrādes un mēbel̦u ražošanas nozarē esošo riska faktoru un arodslimību dinamikas analīze Latvijā laika posmā no 1998. līdz 2005. gadam [Work place risk factors in wood processing and furniture production industries and development of occupational diseases in Latvia in 1998-2005]. Zinātniskie raksti. 2007. gada medicīnas nozares pētnieciskā darba publikācijas (206.-213. lpp.). Rīga: Rīgas Stradiṇa universitāte (in Latvian).

Ostlands, O., Behmane, M., Jakobsena, B., Švarckopfa, A., Vasaraudze, I. (1996). Dž̄ves apstāklıi Latvijā [Living Conditions in Latvia]. Rīga: LR Valsts Statistikas komiteja. 352 lpp (in Latvian).

Palmer, K.T., Griffin, M.I., Syddal, H.E., Pannet, B., Cooper, C., Coggan, D. (2003). The relative importance of whole body vibration and occupational lifting on risk factors for low-back pain. Occup. Environ. Med., 60(10), 715-721.

Sauni, K., Virtema, P., Pääkkönen, R., Toppila, E., Pyykkö, J., Vitti, J. (2010). Quality of life (EQ-5D) and hand-arm vibration syndrome. Int. Arch. Occup. Environ. Health., 83(2), 209-216.

Seidel, H. (2005). The relationship between whole-body vibration exposure and spinal health risk. Industr. Health, 43, 361-377.

Seidel, H. (2008). Selected health risks caused by long-term whole-body vibration. Amer. J. Industr. Med., 23(4), 589-604.

Taylor, W.A. (1994). Occupational vibration. In: Occupational Medicine (pp. 297-304). St. Louis; Baltimor; Boston; Chicago; London; Mosby.

Van Rijn, R.M., Huisstede, B.M., Koes, B.W., Burdorf, A. (2010). Associations between work-related factors and specific disorders of the shoulder: A systemic literature review. Scand. J. Work Environ. Health, No.1, 22-28.

\section{VIBRĀCIJA KĀ ARODA RISKA FAKTORS DARBA VIDĒ LATVIJĀ}

Pētījuma mērkis bija novērtēt vibrāciju kā aroda riska faktoru Latvijas darba vidē dažāēās tautsaimniecības nozarēs. Secināts, ka darba devēji neapzinās vibrācijas potenciālo bīstamību, ko var skaidrot kā uzṇēmumu darba devēju neinformētību par darba vides riska faktoriem, kā arī problēmas neapzināšanos. Gan plaukstas rokas vibrācijas, gan visa k̦ermeṇa vibrācijas mērījumi pēdējos gados norāda uz to, ka vibrācija kā darba vides riska faktors ir pārāk maz analizēta problēma. Vibrācijas izraisīto arodslimību skaits ir pieaudzis gan absolūtos skaiț̣os, gan arī procentuāli no kopējā arodslimību skaita; tas liecina, ka vibrācijas radīto arodslimību īpatsvars Latvijā pieaug. Seviškịi strauji tas ir pieaudzis tādās nozarēs kā transports, lauksaimniecība, mežsaimniecība, kokapstrāde, celtniecība. 